\title{
Towards Sustainable Cities
}

\author{
Mauro ROMANELLI \\ University of Naples Parthenope \\ Department of Business and Economics \\ Via G. Parisi, 13 Napoli 80132 \\ mauro.romanelli@uniparthenope.it
}

\begin{abstract}
Cities of the future should be sustainable, knowledge and innovation oriented, technology-enabled in order to support development and value creation for citizens, businesses, communities, and society. Cities as sustainable organizations should proceed by adopting a smart cities approach as a vision and strategic perspective driving the future urban development. The European framework for designing and implementing smart cities can provide a satisfying path leading cities to plan the urban growth by actively playing an intermediate role in governing and sustaining the 'helices' emerging in the urban area as engines driving processes of innovation and new knowledge creation for sustaining the production of public value. Cities are proceeding towards sustainability valuing and sustaining the 'helices' as source and organizational framework for driving value creation and building a smart approach.
\end{abstract}

Keywords: sustainable cities, smart cities, Triple Helix.

\section{Introduction}

Cities exert influence on the quality of life of people and businesses, as social organisms and ecosystems embracing and using new technologies of information and communication (ICTs) to provide services infrastructures for citizens and businesses by shaping economic systems as engines designing social, cultural and economic development and growth of urban and regional areas. Sustainability as a concept related to building change within public sector organizations is at early stage relying on the use of technology for enabling digital ecosystems and innovation (Harrison, Pardo, \& Cook, 2012; Larsson \& Grönlund, 2014).

New digital technologies offer cities an opportunity to become more and more smart public services-oriented organizations by planning and building a path leading to an urban and sustainable development for creating public value for citizens (Moore, 1995), following a public value management paradigm based on support to relationships trust, legitimacy and outcomes as performance objectives (O'Flynn, 2007) by employing citizens, businesses, communities and governments as active co-producers of public value managing digital technology (Linders, 2012). The 'smart cities 
approach' should offer a strategic vision and design for planning the sustainable cities of future (Albino, Berardi, \& Dangelico, 2015; Caragliu, Del Bo, \& Nijkamp, 2011; Dameri, 2016; Evans, Joas, Sundback, \& Theobald, 2005; Giffinger, Kramar, Fertner, Kalasek, Pichler-Milanovic \& Meijers, 2007; Nam \& Pardo, 2011a, 2011b; Newman \& Jennings, 2008; Williams, 2010). The 'Helices' model tends to emerge as a theoretical perspective and organizational framework for cities 'smart oriented' and strategically driving innovation in providing services, building material, and immaterial infrastructures in order to support growth in urban areas. Sustainable development of cities seems to rely on following both the 'smart cities approach' and the 'Helices' model as drivers for sustaining innovation (Afonso, Monteiro, \& Thompson, 2010; Carayannis, Barth, \& Campbell, 2012; Danson \& Todeva, 2013; Deakin, 2014; Etzcowitz \& Leydensdorff, 1998, 2000; Etzcowitz, 2003; Etzkowitz \& Zhou, 2006; Leydesdorff \& Deakin, 2011; Todeva, 2013).

The aim of this study is to identify a framework leading cities to select a path for proceeding towards a sustainable development over time relying on 'smart cities approach' by sustaining the 'Helices' configuration emerging in urban and regional areas. Cities of the future should be sustainable organizations driving the social and economic development by following a 'smart cities approach' as vision and strategic perspective playing actively an intermediary role and working for building strong relationships among the 'helices' operating in the urban areas as drivers of innovation becoming smarter cities to behave as organizations driven by sustainability.

The sustainability of cities seems to rely on developing and implementing a 'smart cities approach' driven and supported by the 'Helices' model as engine and driver for innovation and development, for knowledge and creative ideas. Sustainability relying on combining technology, knowledge, governance and participation seems to be the result of innovation processes. Innovation as a driver for the social and economic development of urban and local areas and autonomies should be oriented by a strategic perspective relying on the dynamic interaction among the helices and the active role of cities embracing technology to support wider policies for driving urban growth and development. Municipal governments have to behave as an intermediate actor among various organizations and business involving the citizens as users having benefits for all smart and sustainable oriented initiatives and programs leading cities to the future.

This study relies on archival and qualitative data drawn by considering the literature on 'Helices' model as driver and source of innovation and analyzing the issues emerging from the literature on the concept of smart cities by considering the European view on driving the 'smart cities 
approach' as paradigm leading cities to the future development. The study is organized as follows. In the first paragraph, cities are presented as sustainable organizations. In the second paragraph, the 'Helices' framework as a driver for sustaining innovation and development for cities of the future is elucidated. In the fourth and fifth paragraphs both the understanding of smart cities as a concept and strategic vision and European view to 'smart cities approach' and development are presented. In the final paragraph discussion and conclusions tend to follow.

\section{Cities as sustainable organizations}

Cities as settled aggregation of people creating urban organisms and relevant entities for driving the human development of societies and communities tend to play a proactive role in stimulating and fostering social, economic and cultural growth in urban and regional areas. Defining what a city is and which peculiarities cities should have is both a very difficult and intriguing task and field at the same time. In literature, there are many and different definitions about the need of identifying a satisfying concept of what is a city (Bourne, 1971). Organization tends to exist when coordination among organized activities or systems of activities exists being governed by forms of organization (Grandori, 1999).

Cities as geographical and organizational entities have the capability to better exercise some functions having a beneficial impact on the urban area, on the regional growth and development with regard to a surrounding environment that is served and for which cities are producing some beneficial effects, social, cultural and economic gains (Mossello, 1990). Cities as informational and relational networks and spaces tend to continuously change as living and evolving organisms and places as learning systems, knowledge creation and innovation oriented that sustain and support creative and morphogenetic processes over time (Camagni, 1992). Cities are social organisms and expression of the human capacity for driving meaningful communication, social entities displaying both internal and external forms of symbiosis and symbolic communication between individuals (Schnore, 1971).

Cities as sustainable ecosystems made up of living and non-living components are becoming the principal engines of economic growth and places where most of the humanity is living and producing goods and services in the twenty-first century (Newman \& Jennings, 2008). Cities as service and technology oriented communities provide service ICTs-enabled infrastructures and digital platforms for advances services to support 
business and facilitate public life (Anttiroiko, 2014). Sustainable cities are places of social interaction, a locus for engendering creativity as entities that help to sustain, improve and extend the wealth of people within the community (Camagni, 1996). Cities tend to act and behave as sustainable and knowledge-based forms of organization that develop structures and practices for encouraging the creation and the use of knowledge in order to manage, use, disseminate and share knowledge establishing objectives related to social, economic and environmental issues developing programs as beneficial for all the stakeholders by searching for cooperation and collaboration with institutions, businesses, and other member of the community (Leon, 2013). Cities are considered as sustainable places where customers, enterprises, and governments actively contribute to support a sustainable development (Satterthwaite, 1997), and citizens are better informed in order to take by embracing practical ethical considerations in everyday decisions (Haughton, 1997). The label of the sustainability tends to follow a multiplicity of views that make available a set of different options for proceeding towards sustainable urban development. Cities should develop a sustainable path by promoting both a social and technological change (Williams, 2009).

Cities as services providers are areas for life and goods production at the heart of the civilization, and the primary source for producing wealth and creating enterprises. They are emerging as meeting places for inspiring architecture and the great centers for sustaining learning and education, culture and politics, tend to emerge as the main social incubator for driving change and creating social and economic innovation (Evans, Joas, Thundback, \& Theobald, 2005).

\section{The 'Helices' for driving and promoting innovation and development within cities}

Cities are becoming relevant and key actors in shaping the urban, regional and international development and constructing the identity of citizens. Driving cities as public and service oriented organizations, digital ecosystems and platforms relies on using technologies as means for proceeding towards a smart, social, cultural and economic development by employing the 'Helices' models ('Triple' or 'Quadruple' and 'Quintuple' 'Helix') as organizational and strategic framework in order to support and govern processes of innovation and new knowledge creation.

Knowledge-based economies develop by relying on the interaction between government, industry, and universities that contribute increasingly to innovate the existing systems and institutions. Industries, government, and 
universities tend to play a key role for sustaining innovation and development. University as a source for breeding new knowledge and technology in knowledge-based economies, the industry as the locus of the production, and government as the source of providing certain contractual relations to guarantee stable interaction and exchange.

The 'Triple Helix' model emerging by the interaction, the dialogue and search for cooperation among university, industry, and government is considered the key to improving the conditions for breeding innovation in knowledge-based economies and societies (Etzkovitz \& Leydensdorff, 1998), for building a platform in order to contribute to institution formation as to create and promote new organizational formats for creating and driving innovation in innovation proceeding towards a path based on both an endless transition and mediated innovation (Etzkovitz, 2003) implying an internal transformation within each sphere emerging as new mode of knowledge production redefining the borders of endless frontiers oriented to an endless transition (Etzkowitz \& Leydesdorff, 2000).

The path driving to 'Triple Helix' model is evolutionary and dynamic proceeding in transition from both a 'statist model' in which government plays a leading role in controlling universities and industry, and a 'laissezfaire model' in which industry is the driving force with other two spirals acting as supporting structures, and industry, universities and government interact across strong boundaries developing communication systems and leading to a communicative overlap among 'helices' to building a 'triple helix' in which each institutional sphere maintaining special features and unique identity tends to assume and take the role of the others beyond performing its institutional task becoming a creative source of innovation in innovation in order to support the emergence of creativity arising in other spirals (Etzkowitz, 2003): the institution acting as the core spiral changes over time as one spiral replaces the other as the driving force in a 'triple helix configuration' (Etzkowitz, 2003; Leydesdorff \& Etzkowitz, 1998).

Etzkowitz and Zhou (2006) refer to the attribute of sustainability as complement to innovation in order to support the creative dynamic of 'Triple Helix' model. Knowledge and innovation policies and strategies must acknowledge the important role of the 'public' for a successful achieving of goals and objectives (Carayannis \& Campbell, 2009). Afonso et al. (2010) suggest considering the civil society as fourth pillar or helix dialoguing with technological infrastructure of innovation and influencing the economic structure of countries. Carayannis et al. (2012) elucidate that the socioecological transition of society and economy in the twenty-first century is leading to a quintuple helix related to the natural environments as driver 
for knowledge production and innovation: ecology, knowledge and innovation create synergies between economy, society and democracy in terms of citizenship and participation.

Cities as key components of innovation systems and engines of economic growth are considered and viewed as densities in networks among three relevant dynamics: the intellectual capital of universities, industry of wealth creation and their participation in the democratic government of civil society. The perspective offered by 'Triple Helix' model seems to explain how the cultural development relies on developing policies in which governing and local authorities play a relevant and central role in contribution to constructing them. Cities planning to become smarter organizations need to acquire the intellectual capital required in order to emerge as centers of creative slack because of communities exercising a political leadership and selecting strategies for enterprising and opening-up both the economic and governmental dimensions of corporate management (Leydesdorff \& Deakin, 2011).

Triple helices have an impact on economic growth and sustainable innovation outcomes mainly at the local level with industry, universities and other public and third sector actors effectively working with local authorities (Danson \& Todeva, 2013). Three, quadruple or quintuple 'helices' tend to operate within urban areas and mainly in cities planning to become smarter and sustainable over time following an endless transition too. It is also necessary that public or private organizations tend to behave and act as intermediaries governing the strategic choice for allocation of resources (Todeva, 2013).

Three helices operate in a complex urban environment, where market demand, governance, civic involvement and citizens' characteristics, along with cultural and social capital endowments shape the relationships between the traditional helices of university, industry, and government. This perspective tends to emphasize the role of cities as 'smart' and incubators of intellectual capital, enabling the creation of wealth and regulators of standards by involving universities, industry, government and civil society as one of the main key actors in promoting the development and performance of cities being smart (Lombardi, Giordano, Farouh, \& Yousef, 2011). Cities following the 'Triple Helix' model tend to become smart when the ICTs of future Internet developments successfully embed the networks society needs for them sustaining intellectual capital and wealth, developing both the environmental capacity, the ecology and vitality of those spaces enriched by direct democracy and participatory governance adding value (Deakin, 2014). 


\section{Building a 'Smart' and 'European' design for driving sustainable cities}

Cities proceeding towards sustainability should adopt and implement a design relying on following the 'smart cities approach' as paradigm leading cities to the future. The European view to developing smart cities offers a template or guidelines in order to build and implement both smart and sustainable cities and communities.

\section{Understanding the concept of 'smart cities': the constitutive elements}

Cities of the future will be smart communities, sustainable, healthy, culturally strong, ideal places for work and live surviving in the knowledgebased and global information economies and societies playing a central role in improving the competitiveness of the urban system having benefits for the regional and national economy (Begg, 2009; Eger, 2009). Cities of the future will be built along information highways and through the web.

Cities are considered as a space of flows (Castells, 1989) as digital communications technologies were used to create dense real-time networks linking businesses, governments, organizations and individuals around the globe. Policymakers should pay more attention to the evolution of 'smart cities approach' in order to correctly understand regional and urban dimensions of economic development policy. The term 'smart city' is often used to describe a city with a smart industry especially in the fields of information and communication technologies or implying ICT in their production processes. Smart cities are areas within the quality of life is high because of the connections between productivity, growth and human capital (Shapiro, 2006). Smart cities employ strategically and organically the ICTs as innovative support to management and delivery of public services based on a public-private partnership to improve the quality of life of citizens adapting to needs of users and promoting a sustainable development. Smart cities as small and mid-size metropolitan areas containing university and research centers with a large share of the adult population with a college degree are growing in terms of economic and policy centrality because of being considered as centers of higher education attracting persons moving to pursue higher education. The growth of smart cities relies also on calling young people providing them the relevant opportunity for high quality of education and training (Winters, 2011).

Cities tend to behave as smart cities by seeking to address public issues via ICT-based solutions approaching a multi-stakeholder, municipally based partnership. A smart city is enabled by the use of technologies in order to improve competitiveness and ensure a more sustainable future by linking 
and symbiotically combining networks of people, businesses, technologies, infrastructures, consumption, energy and spaces (Manville et al., 2014). Smart cities were defined in the past as digital cities because of employing new technologies for building an arena enabling people in regional communities to interact, share knowledge experiences, and mutual interests by integrating urban information and creating public spaces through the internet for people living and visiting cities (Ishida, 2002). That conceptualization presented lacking elements because of paying attention only on digital and technological component explaining partially the increasing potential of cities in using technology for developing new knowledge, creative capabilities to generate innovation processes.

According to Giffinger et al. (2007) smart city refers to the search for intelligent solutions which drive cities to enhance the quality of services provided to citizens by paying attention to economy, people, governance, mobility, environment, and living identifying the combination of activities relying on aware citizens too. Industry, education, participation and technical infrastructure are generally related to the term 'smart city'. Six characteristics are identified in order to qualify what a smart city should be and concern: smart economy as competitiveness: innovative spirit, entrepreneurship, economic image, productivity, flexible labor markets, ability to transform and international embeddedness; smart people as social and human capital: level of qualification, affinity to lifelong learning, social and ethnic diversity, creativity, cosmopolitanism, participation in public life; smart governance in terms of democratic participation in decision making, transparent governance, political strategies; smart mobility as integration between transports, mobility and use of technology and ICTs: local and international accessibility, ICT infrastructure, sustainable and innovative transport systems; smart environment in terms of attractively of natural resources, environmental protection and risk of pollution; smart living in terms of quality of life concerning: cultural facilities, health conditions, housing quality, education and individual facilities.

Some characteristics are associated to the term 'smart city': utilizing a networked infrastructure for improving economic efficiency and social and urban development; emphasis on business-led urban development and the crucial role of high-tech and creative industries contribute to urban growth; great attention to both social and relational capital's role. Cities tend to become smart when planning investments in human and social capital and develop modern communication infrastructures in terms of transports and technology employed, developing fuel sustainable economic growth for ensuring high quality of life by managing wisely natural resources and sustaining participatory governance (Caragliu et al., 2011). 
According to the French view the 'smart cities' concept comprises at least the following six elements: intelligent, innovative, entrepreneurial, productive and international economy; fluid and fast mobility by accessible, modern, durable and innovative transports; orientation to environmental and energetic sustainability; attention and involvement of citizens in the life of communities; quality of life in terms of ensuring high levels of cultural interest, healthcare, security and education for people; effective and transparent administration for managing public affairs as to make more simple the life of citizens (Auby \& De Gregorio, 2015). Nam and Pardo (2011a) refer to smart city concept in order to develop innovation by including three elements: technology for improving services and enabling a better use of tools technology-driven; organization for creating managerial capabilities for effective use of technology; policy as mechanism for driving institutional urban problems addressing them to construct and enable a smart city. Smart cities initiatives as policy and managerial innovation permits to elucidate that a smart city is both a municipal and global movement, service and evolution-oriented, multi-sectoral, combining and building harmony between the real world and virtual world. Technology, institutional and human factors emerge as the fundamental components of a smart city: the smart city is a center of higher education and smart workforce creativity and knowledge oriented leading to a learning dynamic environment (Nam \& Pardo, 2011b).

Smart cities as intelligent, digital, wired, inclusive and democratic organizations and platforms could have broader boundaries, from the urban dimension towards a more wide and global dimension. Smart cities should define measurable goals regarding the aspects of intellectual capital creation, citizen participation, environmental sustainability and well-being. Four main components (land, technology, citizens, government) tend to emerge through investigation of smart cities initiatives: the land as geographical area on which projects focus; technology, ICTs and digital platforms to improve high quality infrastructures, service and governance; the citizens and people which should both benefit of smart initiative and give a contribution by participation; citizen should behave as active player in the construction of smart cities initiatives; government in terms of public powers and bodies making strategic choices regarding the development of urban areas and territory and future quality of life of citizens living there (Dameri, 2016).

Developing the smart city concept should help to refine the image of cities as common goods and drive citizens to actively contribute and share ideas and values of cities as a common heritage to govern (Cerchiara \& Zupi, 2015). 'Smart city' is a concept future-oriented integrating new 
technologies, social systems and ecological concerns relying on city governments, businesses and citizens embracing and using ICTs in order to reinforce and sustain the role of local community in the new service economies and to improve the quality of life within community (Anttiroiko, 2014). Albino et al. (2015) analyzing different definitions about smart city concept identify the most common characteristics: a networked infrastructure enabling political efficiency, social and cultural development; attention on urban development as driven by business and creative activities for promoting urban growth; relevance and centrality of social inclusion and social capital for urban development; attention on the natural environment as strategic source for future advancements. In sum, analyzing and interpreting the conceptualizations and re-elaborations emerging in the literature it is possible to identify some constitutive elements characterizing the attributes of cities aspiring and strategically planning to become and proceed in the future as smart cities as driver and approach for leading to a sustainable development: the use of technology and ICTs, the active role and involvement of citizens and people within public life and governance, the guiding role of democratic and representative institutions and local government being particularly proactive in driving and implementing policy choices by structuring mechanisms of coordination involving all the actors and private or public stakeholders, providing a strategic design in policy choices and alternatives building, orientation to creating opportunities for encouraging new knowledge creation, orientation to learning and innovation processes, fostering creation and sharing of social and public values.

\section{The European framework for leading cities and communities to be smart and sustainable}

Cities as a key source for driving the sustainable development of the European Union to play a crucial role as engines of the new economy, as places of connectivity, creativity, and innovation, acting as centers of services (European Commission, 2010a). Europe can play a key role in providing a framework and guiding principles enabling cities to design the future development building a vision, engaging citizens and people, mobilizing civil society, organizations, associations, administrations, local resources and stakeholders. According to a European vision, cities of tomorrow should be: places of advanced social progress with a high quality of life and high degree of social cohesion; platforms for democracy, cultural dialogue and diversity, cultural and linguistic, based on good governance principles in terms of openness, participation and accountability; places of green, ecological and environmental regeneration in terms of quality of the environment is protected (European Commission, 2010a). In the European 
scenario, cities should play a relevant role in taking the responsibility of planning and designing growth and development of urban and regional areas. Cities should act as smart and strategic planners and supervisors. The advancement of cities towards a smart mindset relies on cities managing process based on an ongoing dialogue with civil society that can result in the full involvement of group's representative of collective, private or general interests by fostering civic participation (European Economic and Social Committee, 2015).

Building and designing advanced cities, acting as innovation laboratories, rolled out on a large scale, should help to contribute to the industrial and socioeconomic 'renaissance' of the European Union in order to re-launch a genuine industrial, financial and social revolution (European Economic and Social Committee, 2015). European cities are forerunners in the transition towards a resource efficient economy already planning and acting for a more sustainable development by investing in innovative, integrated technologies and services such as buildings, heating/cooling, mobility, lighting, broadband communications and other utilities (European Commission, 2012).

Three priorities are identified in order to sustain European economies and lead to smart, sustainable and inclusive growth: developing an economy based on knowledge and innovation (smart growth); promoting a more resource efficient, greener and more competitive economy relies on acting for enhancing competitiveness, combating climate change by reducing significantly emissions and pollution as to use and employ clean and efficient energy (sustainable growth); fostering a high-employment economy delivering economic, social and territorial cohesion (inclusive growth). Thereby, working and acting for economic growth and development implies to consider more and more the city as a focal point for evolving economies and societies and requires that cities should become smart cities coherently with an orientation towards a smart and clean growth based on knowledge, innovation, and collaboration among various stakeholders involved in sustaining and driving the trajectories of change (European Commission, 2010b).

Cities are becoming more and more of a focal point for economies and societies, in virtue of on-going urbanization, and trends towards increasingly knowledge-intensive economies as well as their growing share of resource consumption and emissions. Cities need to change for meeting and achieving public policy objectives and develop in a smart way in order to become smart cities (European Commission, 2013). "Smart cities should be regarded as systems of people interacting with and using flows of 
energy, materials, services and financing to catalyze sustainable economic development, resilience, and high quality of life; these flows and interactions become smart through making strategic use of information and communication infrastructure and services in a process of transparent urban planning and management that is responsive to the social and economic needs of society" (European Commission, 2013, p.5). Smart cities tend to be considered as drivers for developing a new European industrial policy because cities are viewed as laboratories for a more dynamic, digital Europe in order to demonstrate the opportunity for generating economic growth, increase in employment and sustain social development. Cities will be sustainable organizations relying on innovative technologies and integrated platforms, modern infrastructures, efficiency in the use of energy and redesigning services coherently with needs of the public and users.

Six pillars are identified and have to be enabled to support the concept of 'smartness' in sustaining the development of cities: technologies and tools for energy efficiency and integration of renewal resources; dissemination of technology platforms and connectivity to set up the new digital service systems; new digital services to improve the quality of life and work of the public and businesses; spreading of infrastructure and urban redesigns; education and training of individuals, business and the public sector in digital skills; an economically and financially viable model for investment. Designing a smart strategy applicable to cities relies on sustaining a smart city development model based on: the availability of technologies and tools for energy efficiency and smart electrical infrastructures; dissemination of technology and connectivity platforms enabling the creation of new digital service systems by means of ICT and telecommunications infrastructure; development of new digital service ecosystems for improving the quality of life for individuals and to facilitate business production processes; improving infrastructures and promoting urban redesign in terms of rethinking about the vocation of some areas to be reconverted in projects sustaining the promotion of social innovation; providing training by enabling individuals, businesses and the public sector to upgrade their digital skills as to introduce innovation to be fully used by a wide range of clients and users (European Economic and Social Committee, 2015).

\section{Discussion and conclusion}

Technology offers public institutions, businesses, industry, academia, universities and research centers opportunities to reinforce and rediscover the role of cities as engines promoting urban and regional economic development, as source and organizational form for communities that contribute to building perspectives of social and economic growth and 
development within society. Sustainable cities should build the future relying on both using new technologies by embracing a strategic perspective and playing a proactive role in promoting and managing the governance of 'helices' as model and organizational framework for driving and sustaining processes of innovation in order to enhance social, economic and urban performances and innovation investing in competencies and capabilities in the service of local community, businesses, and society. The 'helices' as an industry, businesses, academia and universities, government, civil society and the public, the natural environment are embedded within cities as urban areas, places, and forms for organizing the life of people and community.

Cities as organizations 'public driven' should play a proactive and central role as intermediary actor in governing the building and configurations of 'helices' to orient the process of innovation. European programs and guidelines prescribe the operational way to construct and plan the cities of future as smart cities. The smart city approach could emerge as a useful paradigm to drive the dynamics of change and innovation as related to building the relationships between use of technology, the role of public institutions, businesses and universities for reinforcing the concept of citizenship. The European view to designing smart cities contributes to providing a template for leading cities to plan and build a sustainable and smart development enabled and driven by technology and knowledge for breeding innovation.

Cities should select a strategic agenda and operational path involving different stakeholders that actively contribute to build and to develop cities of the future as sustainable organizations driven by technology and ICTs, governing the 'Helices' model as necessary driver for innovation and creativity, knowledge and information sharing based, oriented to sustain democratic and participatory forms of cooperation and interaction among individuals, businesses, industries, research centers, universities and other institutions.

Cities as urban and virtual platforms, as spaces and meeting places for innovation and creativity, digitally enabled and technology driven, should contribute to develop sources of knowledge and innovation for constructing processes of innovation that help to improve services for citizens, businesses and societies, to enhance the quality of live, to sustain social and public value creation. The 'smart cities approach' as strategic perspective driving the policy choices of cities and the 'Helices' model as framework and engine for promoting and developing innovation permits to identify a path leading cities to proceed towards sustainability as concept going beyond 
developing a smart approach relying on technology as necessary but not sufficient means, valuing the potential offered by the 'Helices' that cooperate, interact and build organizational forms (multilateral networks and hybrids) to create value and provide solutions in terms of knowledge creation and sharing, diffusion of innovation and learning. Cities select a strategic choice proceeding in the transition from merely adopting digital technologies and ICTs to following a smart orientation for developing and rethinking the urban growth.

The 'Helices' configuration provides a way to work, to build and construct processes and structures for innovation. Linking thinking and action should be the key to lead cities as social organisms and organizational forms to select the path towards a sustainable and enduring development. Cities developing services infrastructures relying on support of 'Triple Helix' model can select a 'digital view' to development, without becoming smart, by improving the technological component and sustaining only digital platforms of services or can adopt, design and implement a 'smart cities approach' for becoming 'smart' relying on technology as means to support services ICTs-enabled having a beneficial impact on land, citizens, policy choice, environment, participation and governance. Cities embracing a 'digital view' to drive the urban development could benefit by involving and combining the great potential emerging from the role of industries, academia, government, civil society or the public, the environment as key dimensions to be considered as an enlarged set of 'Helices' for implementing a smart strategy emerging as a bottom-up plan helping to reconsider and rethinking the path driving cities into the future.

Cities proceeding towards sustainability should follow, combine and value both a 'smart cities approach' and the 'helices' model in order to drive the development of the urban areas. The success and the future of smart cities initiatives will rely on a strategic design identifying the main actors playing a key role in promoting a development based on knowledge sharing and creation, focused on an extended use of technologies, employing actively forms democracy and participation as primary source, and relying on encouraging the proactive role of citizens in the participation to democratic, policy options and choices.

\section{References}

Afonso, Ó., Monteiro, S., and Thompson, M.J.R. (2010). A growth model for the quadruple helix innovation theory. Retrieved from http://www.nipe.eeg.uminho.pt/Uploads/WP_2010/NIPE_WP_1 2_2010.pdf. 
Albino, V., Berardi, U., and Dangelico, R.M. (2015). Smart Cities: Definitions, Dimensions, Performance, and Initiatives. Journal of Urban Technology, 22(1), 3-21.

Anttiroiko, A.-V., Valkama, P., and Bailey, S.J. (2014). Smart cities in the new service economy: building platforms for smart services. AI\&Society, 29(3), 323-334.

Auby, J.-B., and De Gregorio, V. (2015). Le smart cities in Francia. Le istituzioni del federalismo: rivista di studi giuridici e politici, 4, 975-993.

Begg, I. (1999). Cities and Competitiveness. Urban Studies, 36(5-6), 795-809.

Bourne, L.S. (1971). Internal Structure of the City. Readings on space and environment. New York: Oxford University Press.

Camagni R., (1996). Economia e pianificazione della città sostenibile. Bologna: IlMulino.

Camagni, R. (1992). Economia urbana. Principi, concetti e metodi. Roma: La Nuova Italia Scientifica.

Caragliu, A., Del Bo, C., and Nijkamp, P. (2011). Smart cities in Europe. Journal of urban technology, 18(2), 65-82.

Carayannis, E.G., and Campbell, D.F.J. (2009). 'Mode 3' and 'Quadruple Helix': toward a 21st century fractal innovation eco system. International Journal Technology Management, 46(3-4), 201-234.

Carayannis, E.G., Barth, T.D., and Campbell, F.J. (2012). The Quintuple Helix innovation model: global warming as a challenge and driver for innovation. Journal of Innovation and Entrepreneurship, 1(1), 1-12.

Castells, M. (1989). The informational city: Information technology, economic restructuring, and the urban-regional process. Oxford: Blackwell Publishers.

Cerchiara, G., and Zupi, M. (2015). Il coinvolgimento dei cittadini nella costruzione della Smart city: un'opportunità per rafforzare il patrimonio della città. XXVII Convegno annuale di Sinergie. Heritage, management e impresa: quali sinergie? 9-10 luglio 2015, Università degli Studi del Molise-sede di Termoli.

Dameri, R. (2013). Searching for Smart City definition: a comprehensive proposal. International Journal of Computers \& Technology, 11(4), 2544-2551.

Deakin, M. (2014). Smart cities: state-of-the-art and governance challenge. Triple Helix, 1(7), 1-16.

Eger, J.M. (2009). Smart Growth, Smart Cities, and the Crisis at the Pump. A Worldwide Phenomenon. I-Ways Journal of E-Government Policy and Regulation, 32(1), 47-53.

Etzkovitz, H. (2003). Innovation in Innovation: The Triple Helix of UniversityIndustry-Government Relations. Social Science Information, 42(3), 293-337.

Etzkowitz, H., and Leydesdorff, L. (2000). The dynamics of innovation: from National Systems and "Mode 2" to a Triple Helix of università-industrygovernment relations. Research Policy, 29(2), 109-123.

Etzkowitz, H., and Zhou, C. (2006). Triple Helix twins: innovation and sustainability. Science\&Public Policy, 33(1), 77-83.

European Commission (2010a). Cities of Tomorrow - Challenges, visions, way forward. Luxembourg: European Union.

European Commission (2010b). A strategy for smart, sustainable and inclusive growth. Retrieved from http://eur-lex.europa.eu/legalcontent/en/ALL/?uri=CELEX\%3A52010DC2020. 
European Commission (2013). European Innovation Partnership on Smart Cities and Communities - Strategic Implementation Plan. Retrieved from http://ec.europa.eu/eip/smartcities/.

European Economic and Social Committee (2015). Opinion of the European Economic and Social Committee on 'Smart cities as drivers for development of a new European industrial policy' C383/24. Retrieved from http://eurlex.europa.eu/legal-content/EN/TXT/?uri=CELEX\%3A52015IE05 86.

Evans, B., Joas, S., Sundback, S., and Theobald, K. (2005). Governing Sustainable Cities. London: Earthscan.

Giffinger, R., Fertner, C., Kramar, H., Kalasek, R., Pichler-Milanovic, N., and Meijers, E. (2007). Smart cities. Ranking of European medium-sized cities. Final Report. Vienna: Centre of Regional Science.

Grandori, A. (1999). Organizzazione e comportamento economico. Bologna: IlMulino.

Harrison, T.H., Pardo, T.A., and Cook, M. (2012). Creating Open Government Ecosystems: A Research and Development Agenda. Future Internet, 4(4), 900927.

Haughton, G. (1997). Developing sustainable urban development models. Cities, $14(4), 189-195$.

Ishida, T. (2002). Digital city kyoto. Communications of the ACM, 45(7), 76-81.

Larsson, H., and Grönlund Å. (2014). Future-oriented eGovernance: The sustainability concept in eGov research, and ways forward. Government Information Quarterly, 31(1), 137-149.

Leon, R.D. (2013). From the Sustainable Organization to Sustainable KnowledgeBased Organization. Petroleum-Gas University of Ploiesti Bulletin, Technical Series, 65(2), 63-73.

Leydesdorff, L., and Deakin, M. (2011). The triple-helix model of smart cities: A neoevolutionary perspective. Journal of Urban Technology, 18(2), 53-63.

Leydesdorff, L., and Etzkowitz, H. (1998). The Triple Helix as a model for innovation studies. Science and Public Policy, 25(3), 195-203.

Linders, D. (2012). From e-government to we-government: Defining a typology for citizen production in the age of social media. Government Information Quarterly, 29(4), 446-454.

Lombardi, P., Giordano, S., Farouh, H., and Wael, Y. (2011). An analytic network model for Smart cities. In E. Esposito (Ed.), Proceedings of the 11th International Symposium on the AHP (pp.15-18). Sorrento: ISAHP.

Manville, C., Cochrane, G., Gave, J., Millard, J., Pederson, J.K., Kåre, T., Liebe, A., Wissner, M., Massink, R., and Kotterink, B. (2014). Mapping smart cities in Europe. Brussels: European Parliament.

Moore, M.H. (1995). Creating Public Value. Strategic Management in Government. Cambridge: Harvard Business Press.

Mossello, M.T. (1990). Geografia economica. Bologna: IlMulino.

Nam, T., and Pardo, T.A. (2011a). Smart city as urban innovation: Focusing on management, policy, and context. In Proceedings of the 5th international conference on theory and practice of electronic governance (pp.185-194). Reading: ACM.

Nam, T., and Pardo, T.A. (2011b). Conceptualizing smart city with dimensions of technology, people, and institutions. In Proceedings of the 12th annual 
international digital government research conference: digital government innovation in challenging times (pp.282-291). Reading: ACM.

Newman, P., and Jennings, J. (2008). Cities as sustainable ecosystems. Principles and practices. Washington DC: Island Press.

O’Flynn, J. (2007). From New Public Management to Public Value: Paradigmatic Change and Managerial Implications. The Australian Journal of Public Administration, 66(3), 353-366.

Satterthwaite, D. (1997). Sustainable Cities or Cities that Contribute to Sustainable Development? Urban Studies, 34(10), 1667-1691.

Schnore, L.F. (1971). The City as a Social Organism. In L.S. Bourne (Ed.), Internal Structure of the City. Readings on space and environment (pp.32-39). New York: Oxford University Press.

Shapiro, J.M. (2006). Smart Cities: Quality of Life, Productivity and the Growth. Effects of Human Capital. The Review of Economics and Statistics, 88(2), 324335.

Todeva, E. (2013). Governance of innovation and intermediation in Triple Helix interactions. Industry \& Higher Education, 27(4), 263-278.

Williams, K. (2010). Sustainable cities: research and practice challenges. International Journal of Urban Sustainable Development, 1(1-2), 128-132.

Winters, J.V. (2011). Why are smart cities growing? Who moves and who stays. Journal of Regional Science, 51(2), 253-270. 